\title{
Calígula e seu império do nada ${ }^{1}$
}

\author{
Caligula and his empire of nothing
}

\section{Resumo}

Sandro Mira Toledo ${ }^{2}$

Este artigo é uma análise estética de como o absurdo é apresentado na dramaturgia Calígula de Albert Camus. Examino aqui como o autor franco-argelino discute esse tema numa composição artística e como suas teses filosóficas se articulam na estrutura de uma peça de teatro. O fio condutor da análise é o problema da negação que ocupou o filósofo-artista por todo o seu primeiro ciclo de obras e que encontra em Calígula a sua expressão mais significativa. É abordado aqui desde a função simbólica e estruturante que a Lua exerce na trama da peça, se estabelecendo como o ponto de fuga para a perspectiva arrivista e niilista do seu protagonista, ao caráter cíclico do absurdo da existência humana apresentado a partir da relação entre os momentos históricos da criação da peça e do contexto ficcional de sua trama; não ficando de fora, discussões sobre a tirania oriunda de uma liberdade sem limites e discussões sobre a possibilidade da peça Calígula ser ou não classificada como Teatro do Absurdo.

Palavras-chave: Camus. Teatro. Absurdo. Negação. Calígula.

\begin{abstract}
This article is an aesthetic analysis of how absurdity is presented in the dramaturgy Caligula by Albert Camus. I examine here how the Franco-Algerian author discusses this theme in an artistic composition and how his philosophical theses are articulated in the structure of a play. The guiding thread of the analysis is the problem of negation, that occupied the philosopher-artist throughout his first cycle of works and which finds in Calígula its most significant expression. It is approached here from the symbolic and structuring function that the Moon exerts in the plot of the play, establishing itself as the vanishing point for the protagonist's upstart and nihilist perspective, to the cyclical character of the absurdity of human existence presented from the relationship between the historical moments of the play's creation and the fictional context of its plot; not being left out, discussions about the tyranny arising from an unlimited freedom and discussions about the possibility of the play Caligula being or not classified as Theater of the Absurd. Keywords: Camus. Theater. Absurd. Negation. Caligula.

\footnotetext{
${ }^{1}$ Este artigo é uma adaptação de um dos capítulos de minha dissertação de mestrado em filosofia, cujo nome é $A$ criação absurda de Albert Camus; uma análise estética de $\mathrm{O}$ estrangeiro $e$ Calígula, e que foi defendida no dia $1^{\circ}$ de março de 2021 pela Universidade Federal Fluminense (UFF-RJ).

2 Mestre em Filosofia pela UFF. Orcid Id: https://orcid.org/oooo-0002-9319-6668.

E-mail: sandrotoledo@id.uff.br
} 


\section{Introdução}

É objeto de análise deste artigo a maneira com que a contradição imanente ao absurdo da existência humana exposta pela filosofia de Albert Camus se articula em diversas outras contradições em sua peça de teatro Calígula e como a trama desse drama é, por isso, toda tecida de forma contrastante. Também é examinado aqui o modo como o desejo do protagonista Calígula de possuir a lua atua como motor de todo o seu raciocínio absurdo, uma vez que a incessante busca por tornar possível esse impossível o motiva a executar o seu plano pedagógico niilista de eliminar as contradições e os contraditores.

Ao longo das seções deste artigo, essa análise sobre a peça camusiana se desdobrará, por sua vez, em importantes pontos, tais como: a estruturação da dramaturgia Calígula a partir de uma lógica absurda e niilista; a relação existente entre os momentos históricos da criação da peça e do contexto ficcional de sua trama; a apresentação de um desejo irrealizável pela lua como símbolo da necessidade do impossível e como motivador do raciocínio absurdo do protagonista; a negação absoluta do ser humano como fruto de uma liberdade ilimitada; o emprego da lua como ponto de fuga para o desespero niilista do imperador romano; a presença do espelho como símbolo tanto de uma consciência do absurdo quanto de uma vaidade solitária; a contraposição entre a verdade absurda da existência humana e a mentira de uma vida iludida com os deuses; e, por fim, a possibilidade da peça Calígula ser ou não considerada como parte do movimento do Teatro do Absurdo.

\section{Império do nada}

ATO I, CENA I 3

(Alguns patrícios, sendo um bem velho, estão reunidos numa sala do palácio e dão sinais de nervosismo.)

Primeiro patrício: Sempre nada 4 .

Velho patrício: Nada de manhã, nada de tarde.

Segundo patrício: Nada depois de três dias.

Velho patrício: Os mensageiros partem, os mensageiros retornam. Sacodem a cabeça e dizem: Nada.

Segundo patrício: Toda a campanha está vencida, não há nada a fazer.

\footnotetext{
3 Tradução própria.

4 Grifo meu. 
Primeiro patrício: Por que se inquietar antes do tempo? Esperemos. É possível que retorne assim como partiu.

Velho patrício: Eu o vi sair do palácio. Ele tinha um olhar estranho.

Primeiro patrício: Eu também, e perguntei o que ele tinha.

Segundo patrício: Respondeu?

Primeiro patrício: Uma única palavra: Nada (CAMUS, 1993, p. 37).

Tudo começa com nada. A peça Calígula, de Albert Camus, se inicia com um diálogo onde a palavra "nada" impera. Embora dificilmente sua reiterada presença aponte imediatamente para algum sentido definido, ela é capaz ao menos de provocar um certo estranhamento no leitor (ou espectador). A repetição desse vocábulo aliada à maneira como ela ocorre no texto - a enfatizar o caráter cíclico dos acontecimentos - parece, com efeito, sinalizar de algum modo o que está por vir, insinuando, ainda que sutilmente, o rumo do drama.

Na abertura da trama, o protagonista, que dá nome à peça, está desaparecido. Porém, mesmo que a sua identidade só seja revelada em cenas posteriores, a personagem já se faz aí presente, pois todo o diálogo inicial da peça gira em torno de sua ausência. Logo nas primeiras cenas, descobrimos que Caio César Calígula fugira do palácio após a morte de sua irmã e amante Drusila; e que, nesse interim, quando questionado por um dos patrícios, o imperador apenas responde-lhe: "nada". Para a comentadora Raquel Ruivo, essa resposta denota o que pode ser considerado o "primeiro sinal do absurdo", algo que expressa um vazio como estado de alma (RUIVO, 1985, p. 271). É exatamente esse perturbador estado de esvaziamento de Caio César, resumido aí pelo nada, o germe de todo o seu futuro empreendimento de aniquilamento.

A dramaturgia Calígula, pertencente ao primeiro ciclo de obras de Camus5, gira em torno do problema da negação. Como bem observa Ruivo, essa trama aborda o modo negativo de viver. Seu protagonista, levado ao desespero pelo sentimento do absurdo, nega o mundo e as pessoas que nele habitam (RUIVO, 1985, p. 265). Para o professor Roberto Carlos Riberto, a recorrente presença da palavra "nada", sobretudo nos primeiros diálogos da trama, marca essa negação e prenuncia os iminentes comportamento e pensamento niilistas do protagonista da peça (RIBEIRO, 2007, p. 71).

\footnotetext{
5 De acordo com o próprio Camus, este primeiro ciclo de obras, também conhecido como ciclo do absurdo, é composto pelas peças Calígula e $O$ mal-entendido, pelo romance $O$ estrangeiro e pelo ensaio filosófico $O$ mito de Sísifo.
} 
Um projeto niilista engendrado pelo ódio de Calígula ditará, ao longo do drama, todas as suas ações. O imperador interpreta que a utilidade do poder, e por conseguinte o ato de governar, é tornar possível o impossível. Por isso entende que sua liberdade não tem limites, e despreza o mundo assim como a vida humana que há nele (RIBEIRO, 2007, p. 72). Intentando ser fiel a si mesmo, Caio César tentará então despovoar o mundo, tentará até o fim negar a existência humana, incluindo a sua própria. Ou ainda nas palavras de Ribeiro:

\footnotetext{
Calígula não quer momentos felizes, ele procura a felicidade plena na desconstrução da mesma. Presa do desespero humano, o homem quer atingir o inatingível, a plenitude da felicidade. Como essa não é possível, só lhe resta a morte como solução. Calígula busca o nada absoluto no intento de cessar todo o seu desespero diante da vida (RIBEIRO, 2007, p. $75)$.
}

Não obstante, é necessário ter em mente que, sendo uma personagem absurda, Calígula tem uma natureza ambígua. Se por um lado o imperador manifesta-se como um tirano genocida, por outro, ele se comporta dessa forma por se descobrir vítima, como todo ser humano, de um destino trágico, por perceber que a morte é um fim inevitável e injustificado. Após a morte de Drusila, Caio César descobre o quão precária e efêmera é sua vida, mesmo sendo um imperador. Ainda que afirme o seu desejo pela verdade, Calígula nega a sua frágil condição humana, e, mediante um poder ilimitado, intenta seguir até o fim com uma lógica absurda, cuja imperiosa conclusão é a destruição humana. A peculiaridade desse protagonista absurdo está sobretudo nesse modo como reage à descoberta da absurdidade de sua existência, respondendo-lhe com uma negação absoluta.

\section{Entre a história e a ficção: um imperador romano nos palcos da Modernidade}

ATO IV, CENA XIV

Helicon: Se proteja, Caio! Se proteja!

(Uma mão invisível apunhala Helicon. Calígula se levanta, pega um banco com a mão e arfando se aproxima do espelho. Ele se observa, simula um salto pra frente e, diante do movimento simétrico do seu duplo no vidro, taca abruptamente o banco gritando:)

Calígula: À história, Calígula, à história!

(O espelho se quebra e, no mesmo momento, por todos os lados, entram os conjurados armados. Calígula os enfrenta com uma risada louca. $\mathrm{O}$ velho patrício o acerta nas costas, Cherea em pleno rosto. A risada de Calígula se transforma em soluços. Todos o acertam. Num último soluço, rindo e reclamando, grita:)

Calígula: Ainda estou vivo! (CAMUS, 1993, p. 172). 
Os instantes finais de Calígula na peça reiteram a dimensão circular da absurdidade da existência humana. Tudo se iniciou do nada e tudo se encaminha agora para o nada. O enredo que partira da morte de Drusila se encerra então com a iminente morte do protagonista. Todavia, além da própria estrutura da trama, o caráter cíclico do absurdo é demarcado pelas últimas palavras do imperador Caio César, nas quais ele enaltece a sua entrada para história e insiste em dizer que continua vivo. Esses últimos suspiros de Calígula tanto podem ser interpretados como um lenitivo para sua morte inevitável, na medida em que crê partir para ser eternizado pela história da humanidade, como também como uma forma de sublinhar a perpetuação do absurdo na existência humana ao longo dos tempos.

Por um lado, este absurdo perpetuado tem uma dimensão mais subjetiva e existencial por ressaltar que a vida humana não tem sentido, já que não importa o lugar ou a época em que o sujeito esteja inserido, a morte é um fim inevitável para todos nós. Mas, por outro, tem uma dimensão mais histórica e política por mostrar que a injustiça, através de genocídios e outras tantas ações absurdas, foi assídua ao longo da história humana. E esta perspectiva histórica do absurdo, por sua vez, parece ser um dos mais notáveis pontos de distinção entre Calígula e as demais obras artísticas de Camus sobre o absurdo ${ }^{6}$.

A dramaturgia Calígula de Albert Camus7, cujo primeiro manuscrito datado é de 1939, foi publicada oficialmente somente em 1944, durante a Segunda Guerra Mundial - as outras edições com atualizações importantes foram publicadas em 1946 e 1957 (RUIVO, 1985, p. 268). A trama da peça, por outro lado, traz à tona uma atmosfera romana do século I d.C. E para escrevê-la, embora não seja propriamente um texto biográfico, Camus se inspira no documento histórico As vidas dos doze Césares do escritor latino Suetônio (69 d.C.-141 d.C.).

A figura histórica Caio César Calígula (12 a 41 d.C.) foi o segundo imperador da dinastia júlio-claudiana e governou Roma apenas por 4 anos, de 37 a 41 d.C., quando foi então assassinado por soldados da guarda pretoriana. Nos relatos de Suetônio sobre a vida de Calígula, podemos conferir diversos pontos relevantes de aproximação com a peça de Camus, principalmente no que diz respeito ao comportamento do imperador. Caio César foi apresentado por ambos como um

\footnotetext{
${ }^{6} \mathrm{Cf}$. nota 4 deste artigo.

7 Vale lembrar aqui que Albert Camus não foi o primeiro a escrever uma peça sobre o imperador romano Caio César Calígula. Um pouco mais de um século antes, em 1837, o célebre autor francês Alexandre Dumas havia escrito um drama homônimo em cinco atos.
} 
líder popular, excêntrico e que apreciava as artes, como alguém que mantinha relações sexuais com a própria irmã Drusila e como um governante que, fascinado pelo poder, tinha atitudes violentas e cruéis (SUETÔNIO, 2012). O fascínio pelo poder e a crueldade talvez sejam, dentre essas características, as mais emblemáticas na construção do protagonista do drama camusiano, aspectos esses corroborados até mesmo por fontes históricas mais atualizadas:

[...] Caio, conhecido como Calígula (12 a 41 d.C.), tinha uma deficiência fatal: gostava demais do poder e jamais teve uma carreira de líder militar. [...] Caio poderia ter tido sucesso, pois no início gozava de grande popularidade e também entendia de assuntos militares. [...] Infelizmente, logo demonstrou que não tinha a personalidade para liderança quando recebeu poder sem limites; o que realmente tinha eram desejos extravagantes de dissipação pessoal. Governando por meio da crueldade e violência, esbanjou dinheiro do tesouro público para satisfazer seus desejos [...] (MARTIN, 2014, p. 180-181).

A peça Calígula, embora apresente um enredo ambientado na Roma Antiga, teve, como supracitado, sua primeira versão escrita no final dos anos 30 do século XX, nos antecedentes da Segunda Guerra Mundial. Nesse período, "graças à crise e às tensões internacionais, são instaurados regimes ditatoriais na Europa central e oriental, bem como nos países mediterrânicos" (BERSTEIN, 2007, p. 352). Sob forte influência nazista e preponderantemente fascista, o mundo, mas sobretudo a Europa, encontrava-se então imerso numa época de tiranias. Segundo o teórico Martin Esslin, por exemplo, ao longo de todo esse obscurantismo, o nacionalismo, a fé no progresso e diversas outras falácias totalitárias foram propagadas para disfarçar o declínio da fé religiosa, funcionando como suas religiões substitutas até o fim da Segunda Guerra (ESSLIN, 2018, p. 22).

Calígula, mesmo não sendo uma peça histórica, reflete uma preocupação do seu autor nesse período. Estando Camus absorvido pelo problema da negação nessa fase, o imperador romano se apresentava, para o autor, como uma personificação da tirania niilista que assolava o mundo, de uma tirania que escancarava ainda mais a sua injustiça e a sua incompreensibilidade. Os princípios explicativos dos dogmas de outrora não conseguiam mais dar conta das então exacerbadas contradições da existência humana, tendo em vista que o mundo se encontrava, nesse momento, totalmente fragmentado e injustificável. Em plena negação da humanidade pela humanidade, o absurdo imperava mais do que nunca na Era Moderna, e Calígula era o protagonista ideal para encabeçar essa trama niilista. 
A presença ficcional de um imperador romano em palcos modernos também parece enfatizar, de alguma maneira, a implacável permanência do elemento trágico na história da humanidade, reiterando a tragicidade inerente à natureza humana. $\mathrm{A}$ peça Calígula sublinha, de certo modo, essa ligação entre o mundo antigo e o moderno, trazendo para o centro do drama essa angústia humana que é fruto do conhecimento sobre sua finitude e sobre a limitação de sua vontade. Por outro lado, a dramaturgia de Camus, ao passo que traz uma atmosfera da Antiguidade que estabelece explicitamente tal conexão, dá também uma perspectiva radicalmente moderna para o seu protagonista, marcando a distinção entre as dimensões clássica e moderna a respeito da experiência trágica.

Roberto Ribeiro observa, por exemplo, que a experiência trágica ainda se faz presente nos tempos atuais, tendo em vista a permanência do conflito entre o ser humano e a ordem em que está incluído. Todavia ressalta que há uma importante distinção entre o trágico da Antiguidade e o da Modernidade. Enquanto na tragédia clássica, da cisão ontológica entre o ser humano e o mundo resulta uma reconciliação que transcende a ruptura, no drama atual, há um esgotamento na reflexão ou vivência da própria experiência de cisão ontológica (RIBEIRO, 2007, p. 62-63). Desse modo, contrariamente a uma tragédia clássica, não há na peça Calígula a reparação do divórcio entre um herói e o mundo. Há, com efeito, uma forma de reflexão sobre o modo de se pensar o ser humano na natureza sem a possibilidade de qualquer restauração harmoniosa, ainda que o seu protagonista possa manifestar esse desejo, o que, por sua vez, manifesta o caráter absurdo de sua condição trágica.

Por fim, em consonância com sua natureza ambígua, Caio César sempre se mostrou uma figura peculiar para Camus. Segundo Raquel Ruivo, o imperador era para o autor franco-argelino uma espécie rara de tirano, era um tirano inteligente. Calígula, ao contrário de outros déspotas, "sabia que a sua liberdade assentava num poder desregrado. Por isso, consentiu em morrer, o que lhe conferia uma espécie de grandeza que os outros jamais conheceram" (RUIVO, 1985, p. 268). E essa inteligência diferenciada do imperador apresentava-se como um elemento fundamental para Camus mostrar como a tirania não pode ser justificada, ainda que por altas razões. 


\title{
30 impossível lunar de um raciocínio absurdo
}

\author{
ATO I, CENA IV \\ Helicon: Parece cansado? \\ Calígula: Andei muito. \\ Helicon: Sim, sua ausência durou muito. \\ Calígula: Era difícil encontrar. \\ Helicon: O quê? \\ Calígula: O que eu queria? \\ Helicon: E o que você queria? \\ Calígula: A lua. \\ Helicon: O quê? \\ Calígula: Sim, eu queria a lua. \\ Helicon: Ah! (Silêncio. Helicon se aproxima.) Pra fazer o quê? \\ Calígula: Bem!... É uma das coisas que não tenho. \\ Helicon: Claro. E agora, tudo se arranjou? \\ Calígula: Não, não posso tê-la. \\ Helicon: Está entediado. \\ Calígula: Sim, é por isso que estou cansado (CAMUS, 1993, p. 46-47).
}

No início da trama de Calígula, o protagonista, logo após reaparecer no palácio, confessa a Helicon que o motivo de sua fuga é a sua necessidade de possuir a lua. Ainda que não admita a causa, Caio César tem, com a morte de sua amanteirmã, a alma tomada por um incessante cansaço e por um implacável estado de vazio, frutos do seu arrebatamento pelo sentimento do absurdo. É a partir desse seu contato com a morte que o imperador de Roma vê o seu vínculo com a natureza se romper, ele percebe aí a fugacidade e fragilidade da existência humana e se desespera. Completamente desterrado e desorientado, Calígula sai então em busca da lua, pois sente a necessidade do impossível, deseja qualquer coisa que não seja deste mundo - um mundo que agora lhe revela a sua verdade: um lugar arbitrário e injusto. Do alto de sua autoridade, o jovem César não aceita a sua impotente condição humana e, por isso, quer algo que não possui, deseja a todo custo a lua. $\mathrm{O}$ mundo do jeito como está não é pra ele aceitável nem suportável, é preciso ir atrás de outro. É preciso, portanto, encontrar a lua, essa é a sua maneira de tornar possível o impossível, ou a sua tentativa desesperada e equivocada de desmantelar o absurdo.

\section{ATO I, CENA IV}

Calígula: É verdade. Mas eu não sabia disso antes. Agora eu sei. (Sempre natural.) Este mundo, tal como está feito, não é suportável. Então preciso da lua, da felicidade, da imortalidade, de qualquer coisa que seja demente, talvez, mas que não seja deste mundo (CAMUS, 1993, p. 48). 
Calígula tem necessidade do impossível porque não está satisfeito com o modo como as coisas estão. A morte de Drusila revelou ao imperador uma importante verdade: “os homens morrem e não são felizes” (CAMUS, 1993, p. 49). Perante esse evento fatídico, a existência humana apresenta-se para Caio César completamente desnudada, revelando-se aleatória e sem sentido. A presença da morte de alguém próximo desperta em Calígula o sentimento do absurdo, fazendoo experimentar um estado de vazio e mal-estar. Através de uma tomada de consciência, surge no imperador um estranhamento e repugnância pelos seres à sua volta. O mundo se torna insuportável para ele, pois não é como deveria ser. Esse movimento de consciência gera em Caio um cansaço contínuo, pois priva-o do sono necessário à vida. Num ato de desespero, cuja raiz é esse sentimento do absurdo, Calígula parte então em busca da lua, ansiando por qualquer coisa que não seja deste mundo, intentando de algum modo alcançar o impossível.

A lua enquanto objeto de desejo do imperador parece possuir uma importante função de contradição na trama. Se por um lado, a busca pela lua parece ser uma tentativa de restabelecer a comunhão com a natureza, de resgatar o elo perdido; por outro, esse anseio pelo impossível é um modo de negar o mundo tal como ele se apresenta e ir ao encontro de algo que esteja fora dele. É representada, dessa forma, uma tentativa notoriamente irrealizável de fuga, uma escapatória delirante para um outro mundo, o mundo da lua.

Não obstante, é preciso aqui sublinhar que, embora possa sugerir o contrário, isso não mostra uma ausência de consciência em Calígula - de modo algum. Mas essa consciência é enganosa, é nebulosa; tal como se estivesse imersa numa penumbra. Com efeito, a consciência do César não é plena, não é efetivamente lúcida; distintamente do que o próprio afirma, não há nele uma devida clarividência. Em oposição ao que Raquel Ruivo observa, a lua não parece manifestar-se como um “clarão de plenitude”, ao menos não verdadeiramente, mas sim como uma representação dessa penumbra, e a sua procura, uma fuga da luz para as sombras, ou ainda, um engano com falsas luzes, já que a lua é um astro sem luz própria. Portanto, contrariamente ao que Caio César acredita, buscar a lua não seria perseguir a verdade, mas sim se alimentar de ilusões.

Diante de um mundo desmantelado, repleto de contradições, sofrimento e morte, o imperador tem vontade de mudar o destino e a ordem das coisas. Por isso, numa conversa com Cesônia, ele revela o desejo de superar os deuses e assumir o 
papel de senhor do destino dos homens, pretendendo, com isso, fazer reinar o impossível:

\begin{abstract}
ATO I, CENA XI
Calígula: [...] de que me serve este poder tão espantoso se não posso mudar a ordem das coisas, se não posso fazer com que o sol se ponha à leste, que o sofrimento diminua e que os seres não morram mais? Não, Cesônia, é indiferente dormir ou ficar acordado se não tenho ação sobre a ordem do mundo.

Cesônia: Mas isso é se igualar aos deuses.

Calígula: Você também, você me acha louco. E no entanto, o que é um deus para que eu queira me igualar a ele? O que eu desejo com todas as minhas forças hoje está acima dos deuses. Eu me encarrego de um reino onde o impossível é rei (CAMUS, 1993, p. 62-63).
\end{abstract}

Há notoriamente em Calígula uma nostalgia da unidade com a natureza. Todavia, em vez de restituí-la, ele reage negativamente à absurdidade de sua existência e rejeita desesperadamente as suas vulnerabilidades humanas. Primeiro foge da realidade fragmentada do mundo indo em busca de um impossível lunar. Depois, a partir de uma lógica absurda, incorpora a arbitrariedade desse mundo e decreta a destruição de todos os seus habitantes, inclusive de si mesmo:

\begin{abstract}
ATO III, CENA V
(Calígula anda de um lado ao outro. Depois se dirige ao espelho.)

Calígula: Você tinha decidido ser lógico, idiota! Trata-se apenas de saber até onde isso irá. (Irônico.) Se te trouxessem a lua, tudo mudaria, não é mesmo? O que é impossível se tornaria possível, e num só golpe, num só tempo, tudo seria transfigurado. Por que não, Calígula? Quem poderia saber? [...] (Ao espelho, numa voz surda) Muitas mortes, muitas mortes, isso desguarnece. Mesmo se me trouxessem a lua, eu não poderia voltar atrás. [...]A lógica, Calígula, é preciso continuar com a lógica. O poder até o fim, o abandono até o fim. Não, não se volta atrás, é preciso ir até a consumação! (CAMUS, 1993, p. 127-128).
\end{abstract}

A experiência da morte da amada desperta, segundo Raquel Ruivo, um movimento de consciência em Calígula, revelando-lhe a crueza e crueldade do mundo. O mundo mostra-se então como pura irracionalidade e desordem, um lugar sem deuses e caótico, repleto de antinomias e sofrimento. Por um lado, o imperador, mediante essa verdade absurda da natureza, enxerga com repugnância a mentira da vida vivida por todos a sua volta, que, alheios a ela, vivem tranquilamente. Por outro, Calígula rejeita colericamente essa condição absurda da existência humana e acaba negando a humanidade. Tomado por um intenso apetite de absoluto, o imperador quer restituir a todo custo a ordem a esse mundo insuportavelmente arbitrário. Nota-se aí o fundamental conflito absurdo estabelecido entre a sua 
nostalgia de unidade com a natureza e o seu incessante desejo pela verdade, incoerência essa materializada na peça como a sua busca pela lua.

De acordo com a comentadora, Caio enxerga aí a utilidade de seu poder de imperador. Através de seu poder ilimitado, ele quer ensinar a liberdade às pessoas, e o seu plano pedagógico para isso é tornar possível o impossível. "Calígula, pensador lógico-niilista, coerente até o fim da sua vida” (RUIVO, 1985, p. 286), quer impor a sua lógica ao mundo a qualquer preço, mas o custo desse seu raciocínio é exterminar os contraditores e as contradições, isto é, a negação absoluta. E é desse modo, levando a morte a todos, inclusive para si mesmo, que Caio César pretende instituir o seu império do nada.

Calígula, sendo um tirano engenhoso e sádico, institui então um "pequeno tratado da execução" (CAMUS, 1993, p. 88) e solicita sarcasticamente a contribuição de seus conspiradores. Esse tratado do imperador formaliza, por sua vez, o caráter lógico de seu plano ao ser ironicamente constituído por uma estrutura silogística:

\section{ATO II, CENA IX}

Calígula: Sejamos generosos, Helicon! Revelemos-lhes nossos pequenos segredos. Vamos, seção III, parágrafo primeiro.

Helicon (levanta-se e recita mecanicamente.): “A execução alivia e liberta. Ela é universal, fortificante e justa em suas aplicações como em suas intenções. Morre-se porque se é culpado. É-se culpado porque se é súdito de Calígula. Ora, todo mundo é súdito de Calígula. Logo, todo mundo é culpado. Donde se resulta que todo mundo morre. É uma questão de tempo e paciência" (CAMUS, 1993, p. 88-89).

$\mathrm{Na}$ tentativa de destronar os deuses, Calígula estabelece então ordens arbitrárias e age segundo sua própria vontade para acabar com as contradições e os contraditores. Mas seguir esse raciocínio absurdo é desprezar a vida humana e, por conseguinte, ser favorável ao assassinato, tal como observa o próprio Camus em seu ensaio $O$ homem revoltado:

[...]Se nada é verdadeiro nem falso, bom ou mau, a regra será mostrar-se o mais eficaz, quer dizer, o mais forte. O mundo não estará mais dividido em justos e injustos, mas em senhores e escravos. Desta forma, não importa para que lado nos voltemos; no âmago da negação e do niilismo, o assassinato tem lugar privilegiado. Se portanto, pretendemos nos instalar na atitude absurda, devemos estar preparados para matar, dando assim mais peso à lógica do que a escrúpulos que consideraremos ilusórios[...] Assim, tudo seria acertado em nome da lógica, se a lógica pudesse realmente ser satisfeita (CAMUS, 2017, p. 14). 
Entretanto, Camus também afirma em seu ensaio que tal lógica não pode ser plenamente satisfeita, porque a sustentação de um raciocínio absurdo pressupõe a manutenção da tensão inerente ao absurdo, ou seja, pressupõe a permanência do conflito entre a incessante busca humana por clareza e a incompreensibilidade do mundo. Tal conflito absurdo, por sua vez, só se apresenta em um estado de consciência, e como para se estar consciente é preciso estar vivo, a vida se configura como um bem imprescindível para a presença do absurdo.

O autor franco-argelino observa que, desse modo, o absurdo, além de ser essencialmente formulado por uma contradição de forças, nos torna reféns de um desdobramento também contraditório. Pois se, por um lado, com a completa ausência de sentido, inexistindo portanto quaisquer valores e regras, tudo passa a ser possível, inclusive matar; por outro, a manutenção da vida constitui-se como uma condição necessária para o absurdo da existência humana, já que a experiência do absurdo pressupõe um estado de consciência, e este a necessidade de se estar vivo. Sendo assim, se reconhecemos como absurda a existência humana, então também devemos reconhecer a vida como um bem de toda a humanidade. Por isso a sustentação do absurdo requer que rechacemos o assassinato tanto quanto o suicídio:

[...]esse raciocínio admite a vida como único bem necessário porque permite justamente esse confronto, sem o qual a aposta absurda não encontraria respaldo. Para dizer que a vida é absurda, a consciência tem necessidade de estar viva. [...]A partir do instante em que se reconhece esse bem como tal, ele é de toda a humanidade. Não se pode dar uma coerência ao assassinato, se a recusamos ao suicídio. A mente imbuída da ideia de absurdo admite, sem dúvida, o crime por fatalidade; mas não saberia aceitar o crime por raciocínio (CAMUS, 2017, p. 15).

Enfim, ao mesmo tempo que o absurdo torna o assassinato indiferente devido à ausência de sentido e valores, ele põe em xeque o ato de matar, já que a vida é um bem necessário para a sua presença. É por isso que, ao tentar dissolver o absurdo, Caio César acaba incorporando o próprio absurdo, desempenhando o papel da morte na vida das pessoas. $\mathrm{Na}$ intenção de solucionar a contradição existencial, buscando impor ao mundo uma coerência, o imperador acaba incorrendo noutra contradição. Eis aí o grande equívoco do empreendimento de Calígula: não entender que o raciocínio absurdo não pode ser plenamente satisfeito. Por outro lado, até mesmo em seus instantes finais, quando se dá conta, na última cena da peça, que matar não é a solução e se apavora diante da morte que se 
aproxima, Caio César segue fiel à lógica e consegue ver nela um lenitivo para o seu desespero: pois se nada dura pra sempre, “o medo também não dura” (CAMUS, 1993, p. 171).

\section{A felicidade assassina de uma liberdade ilimitada}

No ensaio filosófico O mito de Sísifo (CAMUS, 2014), Albert Camus observa que o ser humano no fluxo de sua cotidianidade, antes de se deparar com o absurdo, vive condicionado a planos e metas, sempre preocupado com um futuro ou com uma justificação para suas ações. Esse indivíduo age como se fosse livre, acreditando que a sua vida tem um sentido, tem um propósito justificado por um ser superior que o faz viver em prol de uma eternidade, bastando a ele apenas fazer as escolhas adequadas. Todavia, ao viver de modo planejado, em prol de um amanhã, a única coisa que tal indivíduo atinge é uma condição de servo de sua própria liberdade, pois passa a contar com um porvir que não só está fora de seu alcance, como também condiciona suas escolhas e restringe suas ações. Ao ser então guiado por tais esperanças ilusórias de uma liberdade superior, o ser humano segue, em sua rotina, um fluxo automático de uma existência banal e alienada, submerso num estado de profunda letargia.

A experiência do absurdo, por sua vez, é o que faz despertar nesse indivíduo um movimento de consciência, extraindo-o do sonambulismo de uma vida mecânica e fazendo-o enxergar a verdade contraditória de sua existência. No caso de Calígula, é a morte de Drusila que o faz tomar consciência dessa verdade absurda da condição humana e deixar de ser um homem preso a uma vida rotineira como seus compatriotas. Todavia, numa conversa com Helicon, logo no início da peça, o imperador, repentinamente exaltado, decide que todos à sua volta devem conhecer e viver de acordo com essa verdade:

ATO I, CENA IV

Calígula: [...]tudo ao meu redor é mentira, e eu, eu quero que se viva na verdade! E, justamente, tenho os meios para fazê-los viver na verdade. Porque eu sei o que lhes falta, Helicon. Eles estão privados do conhecimento e lhes falta um professor que sabe do que fala (CAMUS, 1993, p. 49). 
Quando consciente do absurdo de sua condição, o ser humano se depara com um universo limitado, mas transparente, onde tudo está dado. E é mediante a indiferença pelo futuro e o reconhecimento de seus próprios limites que esse indivíduo recusa toda e qualquer promessa de liberdade eterna e abraça sua liberdade de ação. Entretanto, o tirano Calígula, do alto de sua autoridade de imperador romano, sente-se impelido a desafiar o destino e decide então tornar possível o impossível, decretando que não há mais limites para sua liberdade:

ATO I, CENA IX

Calígula: Não, Cipião, é a virtude de um imperador. (Volta-se com uma expressão de cansaço.) Acabo de compreender enfim a utilidade do poder. Ele dá as suas oportunidades ao impossível. Hoje, e por todo o tempo que vai vir, a liberdade não tem mais fronteiras (CAMUS, 1993, p. 58).

Entretanto, como bem sublinha o próprio autor em $O$ homem revoltado, a exigência de uma liberdade absoluta representa a subjugação das outras pessoas, isto é, um desejo, quando ilimitado, faz com que se negue o outro e se suprima qualquer possibilidade de piedade (CAMUS, 2017, p. 58). Sendo assim, a vontade de Caio César, movida por uma espécie de revolta desenfreada, encontra as condições ideais em seu poder desregrado, propiciando desse modo a realização de um plano pedagógico niilista. Impelido pelo desejo desesperado de tonar possível o impossível, o projeto genocida do imperador encontra livre passagem na ausência de qualquer limite para a sua liberdade. O plano de eliminar as contradições e os contraditores pôde assim seguir seu caminho e fazer seu idealizador se regozijar com sua felicidade assassina.

Na penúltima cena da peça, Calígula, em seu diálogo com sua velha amante Cesônia, reivindica que é feliz - num estado de regozijo, porém, distinto daquilo que normalmente se entende por felicidade:

ATO IV, XIII

Calígula: Quem te disse que não sou feliz?

Cesônia: A felicidade é generosa. Ela não vive de destruições.

Calígula: Então, é que há dois tipos de felicidade, e eu escolhi a dos assassinos. Porque sou feliz. Houve um tempo em que acreditava ter atingido o extremo da dor. Pois bem!, não, pode-se ir ainda mais longe. Ao final desta terra, está uma felicidade estéril e magnífica[...] (CAMUS, 1993, p. 168).

Após ter a sua felicidade questionada por Cesônia, o imperador argumenta que há duas espécies de felicidade: uma generosa e outra destruidora. O seu júbilo, 
por sua vez, seria deste segundo tipo, um gozo sádico que se nutre da seiva da morte, se serve da aniquilação dos seres humanos. Pois, para a lógica de Calígula, assim como é para a do marquês de Sade, se um criador mata e nega as suas criaturas, nada pode impedir um homem de se negar e matar os seus semelhantes (CAMUS, 2017, p. 53).

Mais adiante na cena, enquanto assassina Cesônia, Caio César confessa desafiar a criação ao exercer o papel de senhor do destino dos homens, e afirma que sente-se feliz e livre por ter conquistado a divina clarividência. Esta felicidade, por outro lado, revela a sua natureza ambígua quando o imperador admite a solidão de seu empreendimento assassino:

\begin{abstract}
ATO IV, CENA XIII
Cesônia (assustada): A felicidade é, portanto, essa liberdade pavorosa? Calígula (esmagando pouco a pouco com o braço a garganta de Cesônia.): Pode ter certeza, Cesônia. Sem ela, eu teria sido um homem satisfeito. Graças a ela, eu conquistei a divina clarividência do solitário. (Exalta-se cada vez mais, estrangulando pouco a pouco Cesônia, que se deixa ir sem resistência, com as mãos um pouco oferecidas pra frente. Ele fala-lhe, inclinado sobre seu ouvido.) Vivo, mato, exerço o poder delirante do destruidor, ao pé do qual o do criador parece uma macaquice. Isso que é ser feliz. É isso a felicidade, esta insuportável libertação, este desprezo universal, o sangue, o ódio em torno de mim, este isolamento sem igual do homem que mantém toda sua vida diante dos olhos, a alegria desmedida do assassino impune, esta lógica implacável que esmaga as vidas humanas (ri), que te esmaga, Cesônia, por perfazer, enfim, a solidão eterna que desejo (CAMUS, 1993, p. 169-170).
\end{abstract}

Não obstante, logo após tirar a vida de Cesônia, Caio César se dá conta de que “matar não é a solução” (CAMUS, 1993, p. 170). O imperador percebe aí que a sua liberdade, estando confundida com o ódio, mostra-se, com efeito, como uma negação absoluta e nega a liberdade dos outros. E compreende que, diante de tudo disso, a única coisa que lhe cabe é se manter coerente até o fim e se deixar ser morto, já que "a licença para destruir pressupõe também que se possa ser destruído" (CAMUS, 2017, p. 57).

\title{
5 Um tirano lunático e seu desespero niilista disfarçado de revolta
}

ATO I, CENA III

(A cena permanece vazia por alguns segundos. Calígula entra furtivamente pela esquerda. Ele tem um ar perdido, está sujo, seus cabelos estão encharcados e as suas pernas enlameadas. Ele leva várias vezes a mão à boca. Avança para o espelho e detém-se assim que percebe a sua própria imagem. Balbucia palavras indistintas, depois vai se sentar à direita, com 
os braços pendendo entre os joelhos afastados. Helicon entra à direita. Percebendo Calígula, para na extremidade da cena e o observa em silêncio. Calígula se vira e o vê. Um tempo) (CAMUS, 1993, p. 45).

O protagonista Calígula, logo quando surge, na terceira cena da peça, já demonstra-se completamente transtornado pelo desespero. A morte de Drusila, como vimos, provoca nele um perturbador mal-estar que o impele a procurar obcecadamente a lua e a exercer posteriormente um delirante poder de destruição.

Após essa experiência funesta, o mundo se fragmenta diante de Caio César, e a sua comunhão com a natureza revela-se então uma mera ilusão. A realidade do mundo mostra-se pra ele como insuportável, não sendo como deveria ser. A tomada de consciência dessa absurdidade existencial o faz, por um lado, rejeitar a mentira da vida dos homens à sua volta, e por outro, a querer de algum modo tornar possível o impossível. A procura pela lua manifesta-se então como uma tentativa de Calígula saciar essa sua necessidade do impossível, de querer aquilo que está fora deste mundo terreno. Em certa medida, se desenha aí um movimento desesperado de alienação, um comportamento lunático na medida em que o imperador tenta se exilar desta realidade mundana e se refugiar nesse impossível da lua.

Aqueles que recusaram qualquer outra regra ao mundo que criaram, a não ser a do desejo e a da força, correram para o suicídio ou para a loucura e anunciaram o apocalipse. Os outros, que quiseram criar as regras por sua própria força, escolheram a vã ostentação, a aparência ou a banalidade; ou ainda o assassinato e a destruição (CAMUS, 1993, p. 122).

Distintamente da interpretação de Raquel Ruivo (RUIVO, 1985, p. 271-272), embora Calígula tenha um grau de consciência de sua condição e consiga com isso experimentar o absurdo, essa sua consciência não mostra-se plena, ou seja, não chega a ser efetivamente lúcida, mas sim nebulosa, enganosa; o que não exclui, portanto, a insanidade de seu comportamento. A presença de uma consciência do absurdo não garante a sanidade de Calígula. Com efeito, ao mesmo tempo em que o imperador toma consciência da absurdidade de sua existência e diz querer somente a verdade, ele tenta também fugir dessa realidade saindo insensatamente em busca da lua, de um mundo impossível; assim como depois intenta desesperadamente negar a existência humana, impondo a destruição a todos, inclusive a si mesmo. Há notoriamente uma insensatez no raciocínio de Calígula que retroalimenta o absurdo em sua trajetória, assim como há nele uma consciência insana que o aliena da 
realidade, ainda que deseje a verdade. Caio César é, com efeito, dominado por um surto colérico e sua tirania o leva a realizar um projeto de negação absoluta, isto é, um plano de extermínio da vida humana.

[...]O pensamento revoltado não pode, portanto, privar-se da memória: trata-se de uma tensão perpétua. Ao segui-lo em suas obras e nos seus atos, teremos que dizer, a cada vez, se ele continua fiel à sua nobreza primeira ou se, por cansaço e loucura, esquece-a, pelo contrário, em uma embriaguez de tirania ou servidão (CAMUS, 2017, p. 33).

É verdade que Calígula num primeiro momento se rebela contra o absurdo da condição humana e desafia o destino. No início da trama, por exemplo, Caio César parece realmente crer que se revolta e sacrifica tudo por um bem maior, ou ainda, que age em nome de um valor que, embora confuso, é comum a todos. No entanto, a liberdade ilimitada do poder desregrado do imperador faz com que a sua razão se envenene com o ódio pela criação e se lance numa empreitada de destruição das criaturas humanas. Calígula, que de início apenas blasfemava contra a criação, logo “esquece suas origens, cansa-se da dura tensão entre o sim e o não, entregandose finalmente à negação de todas as coisas" (CAMUS, 2017, p. 40), inclusive de si mesmo. O que parecia ser uma revolta metafísica de Caio César contra a condição humana absurda não demora a mostrar o seu desespero niilista inebriado de ódio. Então, o que no princípio dava sinais de uma insurgência coletiva, logo se revela como um plano cruel de acabar com o bem mais caro a todos os homens à sua volta: a vida.

[...]A solidariedade dos homens se fundamenta no movimento de revolta e esta, por sua vez, só encontra justificação nessa cumplicidade. Isso nos dá o direito de dizer, portanto, que toda revolta que se permite negar ou destruir a solidariedade perde, ao mesmo tempo, o nome de revolta e coincide, na realidade, com um consentimento assassino (CAMUS, 2017, p. 33)

A experiência individual do absurdo em Calígula não se desenvolve posteriormente numa consciência coletiva. A solidariedade do imperador pela injusta condição servil dos seres humanos em relação ao destino é logo suplantada por um arrivismo amargo, que, por sua vez, culmina na destruição da vida, fazendo ele mesmo o papel de senhor do destino dos homens. Então, contrariamente ao que afirma Raquel Ruivo (RUIVO, 1985, p. 276), a reação de Caio César, devido ao seu ideal assassino, perde o direito de ser chamada de revolta. Já Cherea e boa parte dos demais súditos de Calígula formam um movimento de revolta contra as 
arbitrariedades e atrocidades de seu senhor, pois embora também sintam ódio, eles, ao contrário do imperador, lutam por um direito comum a todos, o direito de viver e ser feliz. Todavia, é importante ressaltar que a revolta de Cherea e dos demais não é metafísica, pois não há aí um protesto contra absurdidade da existência humana; mas ainda assim é uma revolta, já que eles são servos que se rebelam contra a condição absurda que seu senhor lhes impõe e em favor de um direito humano:

\begin{abstract}
ATO III, VI
Cherea: Porque tenho vontade de viver e ser feliz. Creio que não se pode ser nem uma coisa nem outra, levando o absurdo até as suas últimas consequências. Eu sou como todo mundo. [...] Para ser lógico, eu teria então de matar ou possuir. Mas julgo que essas ideias vagas não têm importância. Se todo mundo se metesse a realizá-las, não poderíamos nem viver nem ser felizes. Mais uma vez, é isso que me importa.

[...]

Cherea: [...] Mas você é um incômodo e é preciso que desapareça (CAMUS, 1993, p. 131-132).
\end{abstract}

Caio César, por outro lado, tampouco poderia ser considerado propriamente um ressentido, já que em nenhum momento da peça se mostra um sujeito passivo, nem mesmo se apresenta numa prolongada situação de impotência. Mas, em contrapartida, é possível que o comportamento do imperador tenha sido impulsionado num primeiro instante por um ressentimento em relação à criação e aos deuses, um estado de espírito que logo se desdobrou numa espécie de arrivismo, numa postura amarga de negação absoluta, numa atitude niilista que se camuflou de revolta.

Por fim, embora haja, como pudemos notar, consideráveis proximidades entre os significados daquilo que é tido como insano e daquilo que é tido como absurdo $^{8}$, não há aqui uma intenção de extrair uma realidade efetiva da trama, tampouco de determinar um perfil psicológico para o protagonista ou ainda de identificar nele qualquer espécie de patologia. Em contrapartida, ainda que esse drama camusiano não seja propriamente uma peça histórica ou biográfica, não se pode perder de vista a época em que Calígula foi publicado, nem as relações reflexivas que são estabelecidas entre determinados momentos históricos. Pois essa peça materializa, em certa medida, a recorrência, ao longo da história humana, de movimentos que se pretendiam fundamentados numa racionalidade e sustentados

\footnotetext{
${ }^{8}$ Alguns dos significados recorrentemente atribuídos a ambos os termos (absurdo e insano) são aquilo que não tem qualquer sentido ou aquilo que não é aceitável pelas pessoas.
} 
por um valor comum mas que acabaram mostrando a sua vocação niilista, ou ainda, de empreendimentos que se disfarçaram de revolta contra a injustiça mas que acabaram revelando a sua tirania genocida.

\title{
6 Consciência absurda e vaidade solitária: reflexos de um mesmo espelho
}

\author{
ATO I, CENA XI \\ Calígula (insensato): Venham todos. Aproximem-se. Eu ordeno que se \\ aproximem. (Pateia.) É um imperador que o exige. (Todos avançam, bem \\ assustados.) Venham rápido. E agora, aproxime-se, Cesônia. \\ (Agarra-a pela mão, leva-a ao espelho e, com uma marreta, apaga \\ freneticamente a imagem sobre a superfície polida. Ri.) \\ Calígula: Nada mais, vê. Sem mais memórias, todos os rostos escaparam. \\ Nada, nada mais. E sabe o que resta. Se aproxime novamente. Olhe. Se \\ aproxime. Olhe. \\ (Exibe-se diante do vidro numa atitude demente.) \\ Cesônia (olhando para o espelho assustada): Calígula! \\ (Calígula muda o tom, coloca seu dedo sobre o vidro e, com o olhar fixo, \\ diz numa voz triunfante): \\ Calígula: Calígula (CAMUS, 1993, p. 66).
}

Ao final do primeiro ato, Calígula, do alto de sua excentricidade autoritária, convoca alguns patrícios e outras pessoas do palácio para assistirem a sua demonstração de poder e o anúncio metafórico do seu plano arbitrário de execuções; projeto este que se apresentará, dali por diante, como o fio condutor de toda a trama. Caio César, ao desfigurar os reflexos de todos no espelho, demonstra que ele, o imperador de Roma, assume aí o papel absurdo de destino dos homens e, portanto, de responsável pelo esfacelamento de toda a vida humana, incluindo da sua própria. Assim como a lua, o espelho apresenta-se como um signo fundamental na peça Calígula. Esse elemento clássico da literatura ocidental parece, de certa maneira, materializar nessa trama camusiana tanto um caráter consciente e reflexivo do protagonista como sua obsessão por si mesmo.

O espelho parece estar presente na peça como um artifício expositor dos pensamentos do personagem protagonista, servindo, com isso, para salientar também a sua extravagante racionalidade. Enquanto apresenta a engenhosidade da lógica absurda de Calígula, esse signo presentifica o processo reflexivo da personagem, mostrando-a falando consigo mesmo a partir de conversas com seu próprio reflexo no espelho: 


\begin{abstract}
ATO IV, CENA XIV
(Gira sobre si mesmo, desvairado; vai para o espelho.)

Calígula: Calígula! Tu também, tu também, tu és culpado. Então, não é bem assim, um pouco mais, um pouco menos. Mas quem ousaria me condenar neste mundo sem juiz, onde ninguém é inocente! (Com toda entonação da angústia, comprimindo-se contra o espelho.) Tu bem vês, Helicon não veio. Não terei a lua. Mas como é amargo ter razão e ter de ir até a consumação. Como tenho medo da consumação. O ruído das armas! Eis o inocente que prepara seu triunfo[...] (CAMUS, 1993, p. 171).
\end{abstract}

É em monólogos como este ao longo da peça que a tomada de consciência do absurdo por Caio César é explicitada. A visão de sua imagem no espelho demarca, de certo modo, a cisão ontológica entre o imperador e o mundo, demarca o movimento de consciência da sua absurdidade existencial na medida em que se vê, naquele reflexo, completamente desgarrado da natureza. Esse espelho, portanto, parece funcionar como um anteparo tanto para os monólogos reflexivos de Calígula, ajudando a revelar para o leitor (ou espectador) as minúcias do seu raciocínio absurdo, como um anteparo também para esse "eu" apartado do mundo quando descoberto por sua consciência.

Calígula procura encontrar na expressão de seu raciocínio absurdo um meio de dar alguma coerência à incoerência de sua existência, mas também um modo de se comprazer com o absurdo, pois ele sabe que, assim como sua vida, o absurdo também é provisório. Esse homem solitário, ao passo que se isola do mundo através de sua lógica absurda, intenta, feito um dândi, regozijar-se diante de um espelho com sua racionalidade exibicionista.

\title{
ATO IV, CENA XIII
}

Calígula: [...] (Calígula se levanta e faz o espelho virar pra si. Anda em círculos, deixando cair os braços, quase sem gestos, feito um animal.) $\hat{E}$ engraçado. Quando não mato, me sinto só. Os vivos não bastariam para povoar o universo e afastar o tédio. Quando vocês estão todos aí, me fazem sentir um vazio desmedido que não posso olhar. Não estou bem senão entre meus mortos [...] (CAMUS, 1993, p. 165).

O plano genocida idealizado pela lógica absurda de Calígula é fruto de uma necessidade de racionalidade, mas também é fruto de sua excentricidade desenfreada. A sua engenhosidade indiferente à vida humana encontrou consonância em sua vaidade megalomaníaca que não suporta sua impotência diante da natureza. Aos 29 anos de idade (CAMUS, 1993, p. 167), o jovem imperador não aceita a sua frágil condição humana, rejeita com todas as suas forças o envelhecimento, o esfacelamento de sua vida. É por isso que Calígula sente-se bem 
entre os mortos mas não entre os vivos, pois, assim, além de não ter que ver nos vivos o perecimento de sua existência, ele pode ver nos defuntos a insígnia de seu poder. Caio César, portanto, mata também por vaidade, para marcar a sua distinção em relação aos outros homens, afinal ele é o imperador de Roma. E mesmo quando percebe, na penúltima cena da peça, que matar não é a solução, ele insiste até o fim em sua lógica absurda como uma forma também de exibir a sua racionalidade (CAMUS, 1993, p. 167). É essa ambição absurda e indiferente à vida humana, por sua vez, que leva Calígula a se isolar das pessoas e do mundo ao longo do drama, impelindo-o a refugiar-se numa solidão barulhenta, sendo atormentado pela voz de sua própria consciência:

\begin{abstract}
ATO IV, CENA XIV
Calígula: [...] Não há nada neste mundo, nem no outro, que esteja à minha altura. Sei, no entanto, e você também sabe (estende as mãos para o espelho chorando), que bastaria que o impossível existisse. O impossível! Eu o procurei nos limites do mundo, nos confins de mim mesmo. Estendi minhas mãos (gritando), estendo minhas mãos e é você que encontro, sempre você diante de mim, e eu sempre cheio de raiva de você [...] (CAMUS, 1993, p. 171-172).
\end{abstract}

Nos últimos instantes da peça, logo em seguida a este monólogo, Calígula, ao exaltar diante do espelho a sua entrada para a história, busca também ali enaltecerse e atribuir algum valor maior para sua existência, elevando-a a um patamar superior à dos homens comuns. E ao proferir essas palavras tacando um banco no seu duplo no espelho, Calígula admite que sua consciência perecerá junto com sua vida, mas que ainda assim ele será de algum modo lembrado pela história. Para sempre. O seu arrivismo mostra então toda a sua vaidade, pois o imperador manifesta aí sua necessidade de triunfar de qualquer jeito, mesmo sendo inevitavelmente derrotado pelo destino.

Ademais, Caio César reconhece que, de acordo com sua lógica absurda, o seu projeto de extermínio também levará necessariamente a execução de seu próprio idealizador; e, mesmo assim, ele sustenta esse raciocínio até o seu fim, deixando que o matem. Esta voluntária insistência, por sua vez, caracteriza o ato do imperador como uma espécie de suicídio, ainda que ele não tire sua vida com as próprias mãos. Em contrapartida, ao sustentar racionalmente a sua atitude, permanecendo fiel a si mesmo até o fim, Calígula confere ao seu suicídio uma certa grandeza, assim como consegue alcançar finalmente a almejada solidão eterna; uma solidão que, dessa vez, será silenciosa, não mais perturbada pela voz de sua consciência. 


\section{0 artista da negação e sua verdade absurda}

A trama da peça Calígula de Albert Camus é, conforme já apontado, entrelaçada por contraposições entre verdade e mentira. Porém, é interessante observar que esse confronto, constituído a partir essencialmente de uma perspectiva existencial, onde se opõem o absurdo e a ilusão divina, é articulado no enredo a partir também de um propósito artístico interno. Em oposição à farsa da vida humana em comunhão com a natureza propagada pelas divinas artes poéticas, o protagonista da peça apresenta a verdade absurda da existência humana através de sua arte negativa. O imperador brinca, ao longo da trama, de representar papéis, ora fingindo comportamentos e pensamentos, ora utilizando ironicamente os recursos da arte dramática para revelar a absurdidade da vida humana e escancarar a mentira de uma vida iludida com os deuses vivida por seus compatriotas. No entanto, todas essas representações provocativas de Calígula parecem servir de certa maneira como uma preparação para o grande papel que desempenha posteriormente, o do algoz absurdo que nega a vida humana.

Em resposta à beleza do falso acordo entre o ser humano e a natureza reverenciada pelos versos dos poetas, Calígula apresenta ao longo da peça a crueldade de sua poesia assassina. No segundo ato da peça, por exemplo, o imperador ludibria o jovem Cipião ao fingir primeiro concordar com sua visão poética sobre a existência humana para depois revelar a sua vocação sanguinolenta:

\section{ATO II, CENA XIV}

Calígula (comprimindo o jovem Cipião contra si): Não sei. Talvez porque nós amamos as mesmas verdades.

O Jovem Cipião (fremente, esconde a cabeça contra o peito de Calígula): Oh! que importa, já que tudo em mim toma as feições do amor.

Calígula (sempre acariciando): É a virtude dos grandes corações, Cipião. Se ao menos eu pudesse conhecer a tua transparência! Mas sei bem da força da minha paixão pela vida, ela não se satisfará com a natureza. Você não pode compreendê-la. Você é de outro mundo. Você é puro no bem como sou no mal.

O Jovem Cipião: Posso compreender.

Calígula: Não. Esta coisa qualquer em mim, este lago de silêncio, estas ervas apodrecidas. (Mudando bruscamente de tom.) Seu poema deve ser belo. Mas se quer minha opinião...

O Jovem Cipião: Sim.

Calígula: Falta sangue a tudo isso.

(Cipião recua bruscamente e olha Calígula com horror. Sempre recuando, fala com uma voz surda, de frente para Calígula que ele olha com intensidade.) 
O Jovem Cipião: Oh, monstro! Monstro infecto. Você representou 9 de novo. Acabou de representar, hein? E está contente contigo?

Calígula (com um pouco de tristeza.): Há verdade nisso que você diz. Eu representei (CAMUS, 1993, p. 103-104).

$\mathrm{Na}$ abertura do terceiro ato, Caio César surge numa parada de feira, ironicamente fantasiado de Vênus ${ }^{10}$, ao passo que sua velha amante Cesônia recita ao público uma espécie de oração sobre a verdade absurda da vida humana. Mais adiante nesse ato, porém, ao ser confrontado por Cipião, Calígula confessa o propósito dessa sua encenação:

\title{
ATO III, CENA II
}

Calígula: Não se compreende o destino, e é por isso que me fiz destino. Tomei o rosto estúpido e incompreensível dos deuses. É isso que seus companheiros de há pouco aprenderam a adorar.

Cipião: E isso é blasfêmia, Caio.

Calígula: Não, Cipião, isso é arte dramática! O erro de todos esses homens é não acreditarem o suficiente no teatro. Eles saberiam, se não fosse isso, que é permitido a todos os homens representar as tragédias celestes e tornar-se deus. Basta endurecer o coração (CAMUS, 1993, p. 119).

No quarto e último ato, o imperador, num dia consagrado à arte, manda convocar alguns poetas para um concurso de composições improvisadas sobre a morte. No entanto, quando é provocativamente perguntado por Cherea sobre sua participação no concurso, o imperador revela a verdade de sua arte:

\author{
ATO IV, CENA XII \\ Cherea: Vai participar do concurso, Caio? \\ Calígula: É inútil. Há muito tempo que fiz minha composição sobre esse \\ tema. \\ Velho patrício (ansioso): Onde se pode consegui-la? \\ Calígula: À minha maneira, recito-a todos os dias. \\ [...]Calígula: [...]É a única composição que tenho feita. Mas também é a \\ prova de que sou o único artista que Roma já conheceu, o único, entende, \\ Cherea, que põe em acordo seus pensamentos e suas ações. \\ Cherea: É somente uma questão de poder. \\ Calígula: Com efeito. Os outros criam por falta de poder. Eu, eu não preciso \\ de uma obra: eu vivo[...] (CAMUS, 1993, p. 158-159).
}

Calígula assume, desse modo, o lugar dos deuses e representa o papel de senhor do destino dos seres humanos. O imperador, contrapondo à bela e ilusória arte dos poetas, faz de sua própria vida a única arte verdadeira, o ofício horrendo de

\footnotetext{
$9 \mathrm{O}$ verbo em francês é "jouer". Optei, sempre quando nesse contexto, traduzir o termo como "representar".

${ }^{10}$ Divindade cultuada na Roma Antiga como a deusa da beleza e do amor. 
condenar arbitrariamente todas as pessoas à morte. Incorporando a verdade absurda da existência humana, Caio César abusa de seu poder ilimitado e transforma sua rotina imperial numa arte cruel de negar os seres humanos e o mundo, decretando a destruição de todos, instaurando aí o seu império do nada.

\section{Teatro do absurdo ou um teatro sobre o absurdo?}

Calígula de Albert Camus, conforme já observado aqui, é uma peça teatral que notoriamente articula em sua trama importantes teses sobre as contradições do absurdo e a negação da vida humana. Os discursos e ações de seu protagonista, são, de certa maneira, reverberações da arbitrariedade e crueldade presentes ao longo da história humana e escancaradas na primeira metade do século XX.

Dividido em quatro atos de tamanhos equivalentes, o enredo de Calígula possui, tal como um drama moderno convencional, uma estrutura linear com início, meio e fim definidos. As personagens do núcleo principal, sobretudo o protagonista, são em geral bem acabadas, com características e ações precisas. O protagonista da peça homônima mostra-se sempre atuante no enredo; quando não está de corpo presente, tem o seu nome citado nos diálogos dos demais. Toda a trama é tecida em torno das ideias e comportamentos de Calígula, apresentando sucessivos conflitos entre ele e as demais personagens, sobretudo com o seu antagonista Cherea.

Ao longo da peça, importantes considerações da filosofia camusiana são manifestadas nas falas das personagens, ora de forma mais contundente, ora de modo mais fragmentado. Os diálogos e monólogos, ainda que guardem uma certa fluidez oral, possuem em diversos momentos uma argumentação filosófica incisiva:

\footnotetext{
ATO II, CENA II

Cherea: [...]Sem dúvida, não é a primeira vez entre nós que um homem dispõe de um poder sem limites, mas é a primeira que dele se serve sem limites, até a negação do homem e do mundo. Eis o que nele me assusta e quero combater. Perder a vida é pouca coisa e terei essa coragem quando for preciso. Mas ver se dissipar o sentido desta vida, desaparecer nossa razão de existir, eis o que é insuportável. Não se pode viver sem razão (CAMUS, 1993, p. 73).
}

Os monólogos e diálogos em Calígula, além de revelarem a realidade interior de suas personagens, trazendo à tona suas emoções e pensamentos, acabam, portanto, servindo também como uma maneira de o dramaturgo-filósofo intervir didaticamente na peça através da inserção de discursos filosóficos bem acabados. 
Para Martin Esslin, o teórico húngaro que cunhou a expressão "Teatro do Absurdo", a dramaturgia de Camus, assim como a de outros autores de sua época, apresenta a irracionalidade da condição humana através de discursos logicamente bem estruturados, enquanto as dramaturgias do absurdo rejeitam o emprego de recursos discursivos e racionais em sua linguagem. Uma peça do Absurdo não segue, segundo Esslin, uma dramaticidade convencional como faz o drama Calígula de Camus. No Teatro do Absurdo não há, para o teórico, uma preocupação com a representação de acontecimentos. É um teatro de situação que se contrapõe a um teatro de sucessão de eventos; não há nele uma narrativa do destino de personagens. As ações das peças do Absurdo não são construídas a partir do conflito de temperamentos opostos e paixões humanas. As suas ações não se propõem a contar uma história, mas sim a "comunicar uma configuração de imagens poéticas" (ESSLIN, 2018, p. 347).

Martin Esslin argumenta que, enquanto “o Teatro do Absurdo avança um passo além e tenta alcançar uma unidade entre seus pressupostos básicos e a forma na qual eles devem ser expressados" (ESSLIN, 2018, p. 23), a peça de Camus lida com o tema em voga em sua época a partir de formas convencionais. De certa maneira, o teórico húngaro defende que o Teatro do Absurdo é, por isso, uma expressão mais potente e satisfatória da filosofia camusiana do que o teatro do próprio autor franco-argelino.

No entanto, se entendemos que a grande contribuição da filosofia camusiana não está na identificação da absurdidade da existência humana, mas na sua análise das possíveis respostas a essa condição, então a estrutura formal da peça Calígula deve ser considerada condizente com a filosofia do autor. Ora, se a trama da peça apresenta um modo negativo de vida em resposta ao sentimento do absurdo, se seu protagonista nega o ser humano e leva o raciocínio absurdo até o fim, demostrando, desse modo, que a tirania não pode ser justificada nem mesmo por altas razões; então, a utilização de recursos racionais na arquitetura da trama mostra-se uma opção formal plenamente condizente com a filosofia de seu autor. Diante disso, a qualidade das formulações racionais usadas na peça pode ser talvez questionada, mas não o uso em si de recursos racionais.

É também importante lembrar aqui que a constatação da condição absurda da existência humana não era propriamente uma novidade do tempo de Camus esse debate já tinha pelo menos mais de dois séculos. O que se mostrava novo 
naquele momento da história era o quão escancarada estava a absurdidade do mundo humano, o que impelia, por sua vez, à retomada dessa discussão pelos intelectuais e artistas da época. Portanto, o estilo acentuadamente "elegante, racionalista e discursivo de um moralista do século XVIII" (ESSLIN, 2018, p. 23) presente em Calígula mostra-se, ao menos, como uma opção formal consistente, ainda que não seja a mais intrigante dentre as aplicadas nos teatros sobre o absurdo. Enfim, embora Calígula não possa compor o movimento do Teatro do Absurdo por não corresponder aos critérios formais estabelecidos por Esslin, ainda é uma importante peça sobre o absurdo, cuja estrutura formal materializa, com certa consistência, as questões levantadas pela filosofia do absurdo camusiana.

\section{Conclusão}

Vimos, neste artigo, que a peça Calígula resgata o imperador da Roma Antiga - um dos déspotas mais cruéis e excêntricos da história ocidental - para protagonizar a sua trama sobre um raciocínio absurdo levado às últimas consequências de seu niilismo. A dramaturgia de Albert Camus não é uma peça histórica ou biográfica, mas tampouco deixa de refletir a história. No período entre o manuscrito inicial (1939) e a primeira publicação (1944) da obra, o mundo, mas sobretudo a Europa, era assolado pela Segunda Guerra Mundial, uma guerra cuja conflagração é determinada pela ascensão de diversos movimentos totalitários, mormente do nazi-fascismo. A peça de Camus leva para os palcos modernos da "época das tiranias" um dos tiranos mais emblemáticos da Antiguidade, e o faz num gesto de materializar o caráter cíclico da história da humanidade e de presentificar a natureza precária e arbitrária da existência humana.

Enfim, o raciocínio absurdo engendrado por Calígula na peça encontra no seu poder de imperador as condições favoráveis para determinar arbitrariamente que todos devem morrer. É por isso que, aliado ao seu cruel autoritarismo, a engenhosidade e excentricidade de sua inteligência o tornam a figura-chave para demonstrar que a negação absoluta da vida humana não é capaz de ser justificada nem mesmo pelas mais altas razões. 


\section{Referências}

BERSTEIN, Serge et al. História do século XX: volume I: 1900-1945, o fim do "mundo europeu”. São Paulo: Companhia Editora Nacional, 2007.

CAMUS, Albert. (1944) Caligula. Paris: Gallimard, 1993.

CAMUS, Albert. O mito de Sísifo. Trad. Ari Roitman e Paulina Watch. Rio de Janeiro: Record, 2014.

CAMUS, Albert. O homem revoltado. Trad. Valerie Rumjanek. Rio de Janeiro: BestBolso, 2017.

ESSLIN, Martin. O teatro do absurdo. Rio de Janeiro: Zahar, 2018.

MARTIN, Thomas. Dos júlio-claudianos à Idade de Ouro do Império. In: Roma Antiga: de Rômulo a Justiniano. Porto Alegre: L\&PM, 2014.

RIBEIRO, Roberto Carlos. Da tragédia e do trágico: a explosão do limite humano em Ájax, de Sófocles, e Calígula, de Camus. DLCV, João Pessoa, v. 5, n. 1, p. 59-79, 2007.

RUIVO, Raquel. Albert Camus: Calígula ou o sentimento do absurdo. RUA-L, Aveiro, n. 2, p. 241-291, 1985.

SUETÔNIO. Caio César Calígula. In: A vida dos doze Césares. Brasília: Senado Federal, Conselho Editorial, 2012. 